\title{
Governance under the shadow of the law: trading high value fine art
}

\author{
Anja Shortland ${ }^{1}$ (D) . Andrew Shortland ${ }^{2}$
}

Received: 22 March 2019 / Accepted: 12 September 2019 / Published online: 20 September 2019

(c) The Author(s) 2019

\begin{abstract}
The market for paintings by well-known artists is booming despite widespread concern about art crime and difficulties in establishing provenance. Public law enforcement is imperfect, and court cases often are deemed problematic. So how is the thriving art market governed in practice? We analyze the protocols used by the top auction houses to identify and resolve problems of illicit supply_fakes, forgeries and items with defective legal titles-through the lens of institutional analysis. We uncover a polycentric private governance system in which different actors govern distinct but overlapping issue areas, motivated by profit, prestige, or the search for truth. When the financial stakes rise, opportunistic behavior undermines the credibility of private governance. We argue that as litigious, super-rich investors entered the art market, the interaction between public law and the traditional private governance system restricted the supply of "blue chip" art, driving the escalation of prices.
\end{abstract}

Keywords Art market · Fraud · Theft · Private enforcement of rights

JEL Classification $\mathrm{K} 42 \cdot \mathrm{P} 140 \cdot \mathrm{Z} 11$

\section{Introduction}

Recent years have witnessed an explosion in the prices of prestigious art objects (New York Times 2012; Reuters 2016). In 2017, the painting Salvator Mundi, attributed to Leonardo da Vinci, set a new world record at USD 450 million (ArtBasel 2018). Even lesser known works of major artists now command million-dollar price tags (The Independent 2014). Yet, the art market continuously is challenged by criminals. Art is portable and the market famously is opaque (The Economist 2013; The Guardian 2016). Many transactions

Anja Shortland

Anja.Shortland@kcl.ac.uk

Andrew Shortland

A.Shortland@cranfield.ac.uk

1 Department of Political Economy, King's College London, Bush House, 30 Aldwych, London WC2B 4BG, UK

2 Department of Forensic Archaeology, Cranfield University, Shrivenham, UK 
are consummated in cash or in kind, making art a potential vehicle for money laundering and capital flight (Economist 2013; Deloitte 2016). The FBI estimates that thieves steal art objects worth between USD 4 billion and 6 billion worldwide every year (Artbusiness 2015). Looted antiquities are a significant source of insurgent and terrorist funding (Financial Times 2015). Successful forgeries have been sold for millions of US dollars (Financial Times 2016). Some commentators consider art and cultural property crime to be the third largest criminal market after drugs and weapons (FBI 2012; The Times 2014). A survey of industry professionals conducted by Deloitte (2016, p. 143) reports that "around $75 \%$ of all stakeholders surveyed agree that 'authenticity, lack of provenance, forgery, and attribution' are the biggest threats to credibility and trust in the art market."

Despite such concerns, the global art market generated sales of $\$ 67.4$ billion in 2018 , of which the top auction houses Christie's and Sotheby's accounted for $\$ 7$ billion and $\$ 6.4$ billion, respectively; $40 \%$ of total art sales came from items priced more than USD 1 million (ArtBasel 2019). What explains buyers' apparent confidence in what clearly is a very tricky market? Only very limited public resources are allocated to art crime. Few countries have dedicated art crime teams and their budgets are under pressure (FBI 2012). The legal process for the restitution of stolen objects and countering art fraud is complicated: "[L]itigation is hugely expensive and inconvenient for private individuals and businesses alike..." (Deloitte 2016, p. 140). Moreover, critical media coverage of trials means that "nobody looks good in court."1 Instead, buyers and sellers largely rely on the "traditional ... handshake culture of the art trade." (Deloitte 2016, p. 156).

This article applies institutional analysis to examine the private governance architecture in the auction market for the highest-valued fine art (Aligica and Tarko 2012; McGinnis 2016; Ostrom 2010). A multiplicity of private decision-makers has created an intricate system of norms, rules and processes to maintain the trust of buyers and sellers. Rules are enforced in pursuit of private profit and personal prestige, thus maintaining a vibrant trade at the top of the art market that is surprisingly robust against crime.

We also explore the evolving relationship and inherent tension between formal and informal governance. Unlike previous generations of art collectors, today's dissatisfied art investors, fund managers, and the super-rich are more likely to turn to litigation to resolve disputes. Court judgments call the existing rules, norms and processes in the art market into question, resulting in ever more risk-averse behavior regarding attributions and titles. Thus, litigation pushes certain types of artworks out of the market (into "limbo"), artificially restricting supply. The resulting price inflation encourages private agents to innovate and develop better governance solutions.

\subsection{Art crime and the law}

We focus on two major challenges to market confidence. ${ }^{2}$ Firstly, criminals, opportunists and bona fide owners want to sell stolen art, whether from individual heists or large-scale theft during genocides and wars, such as the expropriation of property from Jewish families in Nazi Germany. Secondly, criminals respond to rising prices by producing ever more

\footnotetext{
1 Interview with auction house employee, February 2017.

2 Further challenges, such as money laundering, price manipulation, anti-competitive behavior and conflicts of interest (Deloitte 2016), are beyond the scope of this paper.
} 
plausible forgeries, "improve" existing work with questionable provenance details, ${ }^{3}$ or pass off early copies as originals.

Profits on any object that crosses from the grey/illegal/fake market into the bona fide art market are large. Objects without or with dubious provenance fetch a fraction of the price of an equivalent object with full legal documentation (Financial Times 2015). Art on the black market sells for just $7-10 \%$ of its open market value (FBI 2012). The returns on successful forgeries can be huge (Amore 2015; Charney 2015). The key weakness in the market arises from the passions of collectors: "It is sometimes difficult for even the most coolheaded financial professional to remain emotionless when he or she is about to acquire what could be the final cornerstone of a personal art collection..." (Deloitte 2016, p. 156). Thus, pieces with "dubious provenance" and "debated attribution" can enter the market.

"Dubious" provenance indicates that the object's documentation appears deliberately vague, is inconsistent or unlikely, or is missing altogether. "Debated attributions" occur when specialists cannot reach consensus regarding authorship. Indeed, the highest returns on art are made when newly discovered objects, known as "sleepers", eventually are accepted as autograph works of famous masters. Obviously, nothing is wrong with trying to rehabilitate a "lost" masterpiece. However, passionate collectors unintentionally can create a market for (affordable) objects from the black market (Watson 2007; Felch and Frammolino 2011). Criminals benefit even if just a few dealers and collectors operate on a "no questions asked" basis (The Guardian 2015) or pursue a strategy of "optical due diligence" (Lervik and Balcells 2014, p. 138). Accordingly, the art market has been described as "one of the last Wild-West businesses..." (The Economist 2013).

Governments have four tools to clamp down on criminal and deviant behavior in the art market. First, customs' officers can inspect and seize suspect objects as they cross international borders. Second, the police can intervene if a stolen object is exhibited publicly or listed for public auction (Gill and Tsirogiannis 2016). In some jurisdictions, forgeries can be seized and destroyed (The Art Newspaper March 2014). Third, the original owners of a stolen object may be able to bring a legal claim against the current owner. Fourth, buyers who have been deliberately or negligently misled about the value or provenance of an object can sue the seller (otherwise, caveat emptor applies). Yet, few countries maintain police "art squads". Notable exceptions are the United States (the FBI), Italy (the Carabinieri Division for the Protection of Cultural Heritage) and the United Kingdom (the Metropolitan Police Art and Antiques Unit). They all do excellent jobs in very difficult circumstances, sometimes with the help of volunteers (FBI 2012). Nonetheless, resource constraints mean that the recovery of stolen items is rare (2\% to 6\%) and successful prosecutions are even rarer (Durney 2011; FBI 2012). Notwithstanding a few high-profile cases, art crime rarely is pursued in court (Chappell and Polk 2009) — unless a legal precedent is sought, or an accused party is completely uncooperative. Art law disputes often involve parties from different cultural and legal backgrounds, complicating the legal process for establishing title (Bandle and Theurich 2011; Roodt 2015). For many collectors and (the descendants of expropriated) original owners, litigation is either impracticable or they want to avoid the (usually negative) publicity generated by court cases. We therefore argue that although laws provide a framework for negotiation and dispute settlement, the art market largely is governed privately.

\footnotetext{
3 "Provenance" refers to documents proving the identities of an object's artist or past owners, such as inventory lists, auction and collection catalogues, and sales receipts.
} 


\subsection{Private governance}

We examine the top-end market for high-valued fine art-specifically the auctions and private sales at Christie's and Sotheby's, venues where the most prestigious paintings owned previously by private collectors, dealers and occasionally museums are traded (Singer and Lynch 1994). Despite the market dominance of those famous auction houses, the governance system is not hierarchical. As Polanyi (1951) points out, abstract ideals such as "beauty", "justice", and "authenticity" cannot be imposed on market participants by an overarching authority. Tastes evolve as artists and gallerists create demand for new art forms or educate their customers to appreciate particular styles. Turnover is continuous as new galleries and artists become fashionable, established dealers retire, collections are dispersed, and new collectors with different appetites emerge. Each jurisdiction chooses how to define property rights. The organisational system must therefore give individuals freedom to structure their activities as they see fit in search of their abstract end-goals (Aligica and Tarko 2012).

The art market is not dominated by the ethnic or kinship networks often observed in informally governed markets (Bernstein 1992; Greif 1993; Landa 1994; Richman 2017). That is because governance challenges arise not only from insider opportunism, but also from (criminal and misinformed) outsiders, differences of opinion, and divergence of laws between jurisdictions. Collectors, dealers and auctioneers may not be aware of problems with the authenticity or legal title of a painting - or refuse to accept others' definition of what constitutes an "authentic" painting or a "good" title. ${ }^{4}$ The system must therefore facilitate competition between taste-makers, dealers, market-makers, experts and other service providers.

We use the framework of polycentricity to analyse the art market's governance system (Ostrom 2010). We show that the tertiary art market shares the key features of previously described polycentric systems, namely, many autonomous competing decision-making centers operating under an overarching set of rules (Aligica and Tarko 2012; McGinnis 2016). By looking at the interests of and interactions between the actors within the system we can explain and rationalize the existing rules of the game and trace their origins. Trust in the art market largely is based on reputation and we observe a very interesting pattern of regulatory arbitrage for the highest valued objects: a flight to quality. The top auction houses have located in jurisdictions with strong legal protection for buyers and original owners. We also identify current challenges to the integrity of the system and show how private agents work to overcome them.

\section{The market for fine art and private governance}

The top end of the art market has several interesting features. Individual art objects are unique -we are dealing with an "extreme case of a heterogeneous commodity" (Thorsby 1994, p. 4). For "noted" works of deceased artists, the supply is (or should be) entirely inelastic. Collectors buy art for different reasons. As a consumer good, the decorative quality

\footnotetext{
4 e.g. the world's most expensive painting, Salvator Mundi, is considered by some experts to be an authentic work of Leonardo da Vinci. Others consider it to be a poor copy, a painting by the Leonardo workshop, a deliberate forgery, or a painting that has been restored to the point of obliterating the original artist's hand-whomever that may have been. (Lewis 2019).
} 
of an object provides immediate consumption services. Owning famous art also confers status. Well-known artworks are (Thorsten) Veblen goods: the higher the price, the more "elite" the owner (Plattner 1998). Furthermore, art may be bought as an inflation hedge or as an investment (Reitlinger 1961; Thorsby 1994). Prices for individual objects depend on developments in those interrelated markets: Deloitte (2016) describes art as a "passion asset”.

Art prices are highly volatile (Ashenfelter and Graddy 2011; Baumol 1986). Overall, the most important correlate of the expected return to owning art is the reputation of the artist (Thorsby 1994). However, high prices attract forgers who produce credible copies or paintings "in the style of" a fashionable painter. Art students' or workshop copies may be bought by fraudsters who add a famous artist's signature and a bogus provenance. Buyers rarely have the expertise to identify fraud - or are misled by their enthusiasm when offered a "missing" masterpiece. Experts estimate that between $10 \%$ and $40 \%$ of the works of notable artists available for sale may be forged or "over-restored" (New York Times 1999). Moreover, elevated prices tempt art thieves and looters into the market. Once a stolen object has passed through a series of bona fide owners and statutes of limitation have expired, it is difficult for a lay person to spot an impaired title. Art therefore is a credence good (Ekelund et al. 2017).

What maintains buyers' evident trust in the market for high value fine art? Singer and Lynch (1997) point out that auction houses invest heavily in the production of information. Such investments raise the probability of authenticity and good titles, encourage risk averse bidders to come forward, and make bidding more competitive (Ashenfelter 1989). Higher prices raise the income premiums (rents) of auction houses. Indeed, we find many businesses specializing in answering the two key questions: "what is it" and "who owns it"? Even the best auction houses and museums occasionally are in the news over fakes, forgeries and looted items (e.g., Al Ahram 2013, BBC 2016). The very publicity associated with such cases suggests that mistakes are rare, but authenticity clearly is not $100 \%$ assured. Yet prosecutions are extremely rare, indicating that in practice it is not the state that orders the market and corrects mistakes. We therefore examine how private agents obtain, collate and share relevant information on art objects. We also analyze informal solutions for resolving disputes and correcting mistakes.

The academic study of polycentric governance traces to the work of Elinor and Vincent Ostrom and the Bloomington School (see Aligica and Boettke 2009; Cole and McGinnis 2015; McGinnis 1999, 2016; Ostrom 1972, 1990, 2005, 2010; Ostrom et al. 1961). Initially, that literature focused on common pool resources, but soon was extended to examine public goods' provision, such as law enforcement and local government (Ostrom 2010). The literature on polycentric governance emphasizes the ability of people to design rules, processes, and enforcement mechanisms to capture benefits from cooperation. Gains are allocated in such ways that spontaneous order systems are sustainable over long time horizons-without government intervention (McGinnis 2016).

Aligica and Tarko (2012) and Ostrom (2010) identify three basic features of polycentric governance. Firstly, a multiplicity of decision-making centers, operating in distinct but overlapping areas. Secondly, stable, ordered relationships based on a system of rules that may be enforced institutionally or culturally. Thirdly, spontaneous order generated by evolutionary competition between agents using different ideas and methods. Current research into polycentricity applies the Ostroms' insights to an ever wider set of complex governance systems, such as science, the free market and the common law (Aligica and Tarko 2012; Tarko 2015). However, not every complex, multi-actor system necessarily is a bona fide polycentric governance system in the spirit of the Bloomington School. If some 
power-holders enforce rules for others, but are not accountable to the same restrictions, and the oppressed cannot change the rules to improve their outcomes, then the system is more accurately described as dominated rather than polycentric (McGinnis 2016). We first identify the active and latent decision-centers within the governance of the art market. We then describe the rules and norms governing that market, show how they incentivize agents to provide suitable services, and explore how insiders adapt the rules over time.

\section{A polycentric private governance system}

Art buyers bidding at high-profile art auctions seek to acquire enforceable titles to authentic art objects. Achieving that goal implies two governance domains: governance of title and governance of authenticity. ${ }^{5}$ Within each governance domain, three critical governance functions can be identified: standard setting, monitoring/evaluation, and enforcement/dispute resolution (Salter 2001; Shortland 2018). "Good" or "effective" governance requires the fulfilling all three functions at least at some threshold level (Agnafors 2013).

Before going into the details, we introduce the agents in the system here. Governments set standards regarding legal titles: each country defines what constitutes a "good title" within its jurisdiction. However, governments rarely allocate adequate resources into monitoring or enforcing titles. Regulatory arbitrage is possible (and, hence, interjurisdictional competition), activated by choosing the most suitable location for each sale. Art insurers set their own standards in the domain of titles, insisting that it should be impossible ever to obtain good title to stolen (or looted) items. Unlike governments, insurers have created institutions for monitoring, enforcement, and dispute resolution, making them the primary provider of governance services in the title domain.

Top-tier auction houses check the legal titles and allocate significant resources to evaluating the authenticity of objects. Auctioneers decide how to market an object consigned for sale: as an authentic work of a noted artist, or as a copy, the work of a follower, or a workshop, and so on. Competition between auction houses is vigorous: selling works labelled as "authentic" brings higher commissions-but also the risk of discovery, loss of reputation, and claims for compensation from disappointed buyers. Monitoring and evaluation are carried out both pre- and post-sale by collectors, professional buyers, and dealers supported by a range of experts. Experts are in competition with each other to provide credible evaluations of an object's authenticity. Scholars peer-review each other's work, pointing out flaws in others' techniques and innovating to enhance their own reputations. Intervention and enforcement may be carried out by courts, but in practice auction houses usually prefer private dispute resolutions. Most cases are settled informally, but legal experts may be employed.

\subsection{Governments}

Two main legal instruments order the art market. The law on theft is straightforward. However, the relevant question for the tertiary art market is how to adjudicate between the legitimate claim of someone who bought an object in good faith (often from a prior good-faith owner) and the person who owned it before a theft. The United States (and, in particular,

5 The domains sometimes are called "dimensions" or "components" of governance. 
New York) applies the nemo dat quod non habet rule: buyers can acquire good title only if the seller had good title (Yip 2010). The rule protects the property rights of a legitimate owner whose property was stolen or expropriated unlawfully over time, regardless of how many people have bought the item in good faith since the initial theft (Yip 2010). European jurisdictions usually apply the principle of "adverse possession": after a specified time limit a bona fide buyer acquires "good title" legally regardless of the object's origin, putting the onus on the victims of theft to track down stolen objects. If a stolen object is identified within the given time limit, it can be seized by the police or customs' officers. However, law enforcers do not routinely monitor art sales. In 2018-2019, the UK's Metropolitan Police art unit consisted of two detective constables, who were forced largely to rely on interested parties to bring problems to their attention. ${ }^{6}$

The second body of law applicable to the art market is that of fraud. Fraud means deliberately making a false or misleading representation or withholding salient information with the intent of making a gain or cause (the risk of) loss to another. ${ }^{7}$ Regarding forgeries, the charge would be fraud by "false representation". That charge is relatively straightforward to prosecute. In public auctions, however, the legal issue usually is one of "failing to disclose information". Here, the claimant must prove that the sellers had in hand the relevant information, that they were under legal obligation to disclose it, and dishonestly withheld it to make a gain. Yet. no absolute standard of authenticity exists. The authorship of many art objects simply cannot be attributed with certainty and experts often provide conflicting "opinions". Bringing a successful prosecution (even under the Trade Descriptions Act) therefore is very difficult. Few people even attempt it (Chapell and Polk 2009). The legal system therefore leaves gaping voids in the governance of the art market. We examine how they are filled by private governance.

\subsection{Insurers and the market for stolen art}

Insurers provide private governance services in the art market to limit the volume and value of stolen art. If stolen art could be sold freely, art theft and insurance premiums would rise. Underwriters specializing in the insurance of high value artwork reduce both the ease and profitability of art theft. The former is achieved by offering a host of security consulting services for art collectors (Private Art Collector 2014) and by shielding the identities of private collectors at auctions. The latter is accomplished by making it very risky to sell high value stolen art in the open market (Artbusiness News 2015)—regardless of whether the auction is conducted in a jurisdiction that applies the nemo dat rule.

The main private governance instrument is the Art Loss Register (ALR): the world's most comprehensive database of missing art and artefacts. The ALR was created in 1991 by a group of specialist underwriters at Lloyd's of London. Insurers, police and private individuals can record details of any art object that is reported stolen in the register (Durney 2011). National police databases usually contain just a few thousand items and it often is cumbersome to search them (The Times 2014). By contrast, the ALR contains information on around 500,000 items and can be consulted for a fee or by subscription. ${ }^{8}$ Auction

\footnotetext{
6 The entire Metropolitan Police art unit was reassigned to investigating the Grenfell tower fire in August 2017 for several months (Telegraph 2017).

7 Whether an actual loss occurred is irrelevant, as is whether the attempted deception succeeded (UK Fraud Act 2006).

${ }^{8}$ May 2019 communication from Julian Radcliffe, owner of the ALR.
} 
houses, dealers, and the organizers of art fairs routinely consult the register. ALR staff check the provenance of each item and look for matches in the database. An object can be bought or sold "in good faith" (which affords the buyer some protection) only if it has passed the ALR test. Both Christie's and Sotheby's are ALR shareholders. For many years, the ALR enjoyed monopoly status and still is considered by many as the "super-authority" on stolen art. The quality of the ALR's services is monitored constantly by its clients, who suffer a reputational loss if they are exposed as selling or having sold stolen objects. Since 2014, the ALR has faced competition from the Art Recovery Group, indicating that the market for the governance of title is contestable: shortcomings and mistakes can be punished by transferring business elsewhere (Independent 2016; Private Art Investor 2015).

If title problems are raised by an ALR search, auction houses postpone the sale or reject the consignment discreetly. It is up to the owner to resolve the title issue. Because the art market is global, it frequently is not clear what law applies: the jurisdiction of the owner, the last point of sale, and the claimant all may apply different standards. Without an absolute international standard of "good title", the issue often is settled by private arbitration (e.g., Maria Altman's case over Klimt's "Woman in Gold") or negotiated by private law firms. Stolen paintings sometimes can be retrieved informally from the criminal underworld, once thieves realize that the object is unsaleable. ${ }^{9}$

\subsection{Auction houses and experts}

Before accepting a consignment, auction house experts screen every item for authenticity and legal ownership. Ideally, an object's provenance should resolve both issues, but the full paper trail of historical documents remains intact only rarely over the centuries (Charney 2015). Moreover, when provenance research was the main governance instrument for establishing authenticity, fraudsters infiltrated and falsified the archives of major collections and sold insignificant paintings on the strength of entirely bogus provenances. Others sold forgeries with the impeccable provenances of genuine paintings and then sold the originals as well, doubling their profits (Charney 2015; Salisbury and Sujo 2009). In-house experts therefore examine each object visually for the possibility of fraud. If suspicions arise, they consult established external experts in the relevant field, including connoisseurs, art historians and scientists.

A connoisseur is someone with considerable experience in their field, perceived to have "the eye" or instinct to pronounce whether an object is "consistent" with the style of the artist or period (Hook 2013; Spencer 2004). However, even highly respected connoisseurs make mistakes (e.g., Lewis 2019, p. 171), and their opinions can be influenced by many extraneous factors (Ginsburgh and Van Ours 2003). Art historians therefore also consult the archival record. They examine the contexts of artists and workshops and produce timelines of output or styles. Scientists test whether the materials used in making the object are of the correct period and origin. They often specialize in particular periods, object types, or analytical methods. For example, modern forgeries might contain titanium white - a pigment that became available only in 1916, followed by several subsequent reformulations (Rogge and Arslanoglu 2019).

\footnotetext{
${ }^{9}$ The ALR offers an art recovery service for owners frustrated with (the lack of) police assistance in tracking and recovering stolen art. That option is controversial, as rewards are offered for information leading to the recovery of stolen items, making it possible that thieves benefit from their crimes (New York Times 2013).
} 
When forgers become aware of new testing procedures, they may acquire the testing equipment or submit their works for testing posing as innocent collectors (Amore 2015; Charney 2015; The Guardian 2018). The result is an arms race between forgers and academic and commercial scientists. Analytical techniques continuously are refined to maintain reputations for reliably identifying fakes. However, if a scientist pronounces an object to be of the "correct period/material", the question of authorship still needs to be settled (Fincham 2017).

A positive evaluation by a key expert can set the price of an object skyrocketing. Commercial pressure to "authenticate" objects thus is considerable. However, each opinion that is exposed subsequently as ill-founded or opportunistic undermines the expert's reputation. The overriding goal of the scholarly community is to protect the integrity of artists' oeuvres and the historical record (Spencer 2004; Fincham 2017). Querying items subsequently exposed as a fake or forgery raises the experts' academic status and the (commercial) demand for their expertise. Museum curators, scholars, dealers and professional buyers thus routinely study auction catalogs and visit pre-sale exhibitions. They alert auctioneers to anything that looks "wrong" and needs further investigation. In the small community of scholarly experts, gossip quickly discredits opportunists and authentication methods that have been "cracked" by forgers. Such reputational solutions based on continuous dealings are common in private governance systems (Leeson 2008, 2014; Stringham 2003).

The system works well as long as experts value the future returns from being perceived as truthful and accurate more than the short-term gains from supporting a dubious object. With continual innovations in forensic science and lively academic debates about attributions, charlatans and opportunists must expect to be discovered eventually (Charney 2015). Yet, experts sometimes authenticate opportunistically when their time horizons are short, ${ }^{10}$ when they are paid to conduct research for an interested party, or when the prestige gains from potentially rehabilitating a "missing masterpiece" are so high that they develop their own cognitive biases (e.g., Margaret Dalivalle's and Martin Kemp's research on Salvator Mundi, according to Lewis 2019). Knowing that, the art market looks increasingly for expert consensus on high-profile works rather than acting on a single endorsement. Thus, "[t]he speculative attribution of unknown or relatively unknown works to major masters is a graveyard for historians' reputations" (Kemp 2007, p. 201).

The academic process of building consensus on the authenticity of objects thus is fairly robust, albeit slow (e.g., National Geographic 2015, The Art Newspaper January 2016). Even scientific opinions are not completely watertight. Mistakes can be made: interpretation of test results is far closer to the opinion of the connoisseur than many scientists would like to admit. While experts debate attributions, auction houses must maintain the trust of the potential sellers. Auctioneers would be ill-advised publicly to cast doubt on the reputation of objects offered for sale: today's seller is tomorrow's buyer. The system therefore has not developed a mechanism to force sellers, dealers, or auction houses to disclose negative expert reports. Even if no explicit confidentiality clause is inserted into the expert's contract, it is "understood" that damaging information will not be divulged to third parties. Negative expert opinions sometimes become public if a case is taken to court and it may then be found-as in the case of the forgeries traded by the Knoedler Gallery - that multiple experts had raised concerns (e.g., The Art Newspaper August 2016).

\footnotetext{
${ }^{10}$ Lewis (2019, p. 171) and Spencer (2004, p. 75) supply examples of ageing specialists whose connoisseurly opinions reached "junk status" among their peers when their standards slipped.
} 
An item's auction catalog entry therefore is the outcome of a deliberative process. The critical information is provided in the Bold Print Heading or in UPPERCASE type in the first line of the catalog. In fine art sales, the first line provides information about the painter. The item's entry then gives a brief description: the title of the work, the medium, its size, whether and where it is signed and when it was produced. Any damage and repairs are mentioned. One or several pictures may accompany the text. That is followed by the auctioneer's estimate of the likely range of the sales price. The catalog also details the provenance of the object. Ideally, the first entry in the Provenance section links the object directly to its maker, followed by an unbroken line of owners and consensual sales. Prior owners are disclosed only if their collection is prestigious and their names add to the cachet (and, hence, price) of the object. Mostly the catalogs list when and where the object was sold. In addition, catalogs often state the identity of the person confirming the authenticity of a painting. Inclusion in a widely accepted catalog of an artist's works-a Catalogue Raisonné - is the gold standard. ${ }^{11}$ Otherwise, favorable expert opinions and less respected catalogues are cited. The final section of the catalog entry details any occasions when the object has been exhibited publicly and any books in which it has been included. That information adds prestige, but also reassures buyers that any defective titles, restitution claims, and criticisms of the current attribution already would have come to light. ${ }^{12}$

Only the title line of the auction catalog is guaranteed. Doubts about attributions are indicated by adding a question mark or describing an object as "Workshop of...", or "Follower of..." rather than just the presumed artist's name. The description below the title line represents the opinion of the auction house (or the cited experts) and is not covered by any form of warranty. That is understood by all. A low estimate reflects the auctioneer's opinion about how compromised the object is by the difficulty of establishing its maker. It is then up to buyers to decide whether they want to take the risk of trying to rehabilitate the object—or buy it because they like it anyway. In any case, for some buyers the perception of authenticity may be more important than the truth (Charney 2015, p. 23).

Despite considerable effort to establish an objective opinion before the sales catalog is printed, mistakes happen occasionally. Expert and public scrutiny of the auction catalog and pre-sale exhibitions act as further gatekeepers to problematic paintings. If credible restitution claims are made by the original owners, or a respected expert casts doubt on an attribution, objects are withdrawn from sale until the question of ownership or authenticity has been settled.

To reassure buyers further, auction houses offer legal protections, detailed in the "Terms of Guarantee": Subject to specific exclusions, sales can be rescinded within five years of the sale if the description "set forth in the Bold Type Heading ... is not substantially correct based on a fair reading of the catalogue..." (Sotheby's 1989, p. 2; emphasis in original). However, auction houses are not liable if the "catalogue description at the date of the auction was in accordance with the then generally accepted opinion of scholars or experts..." (Christie's 1994, p. 117). Liability also excludes forgeries that come to light using new scientific techniques "not generally accepted for use until after publication of the catalogue" (Sotheby's 1989, p. 2) or "... by means of a process which at the date of the

\footnotetext{
11 Several rival catalogs by different authors may be available, but insiders will consider one catalog to be authoritative or at least conditionally accurate (Findlay 2004). Catalogs are revised periodically, and artworks included previously may later be demoted (Fincham 2017).

12 For example, the Christie's sales catalog for Salvator Mundi features copiously its inclusion in the National Gallery's blockbuster Leonardo exhibition.
} 
auction was unreasonably expensive or impracticable or likely to have caused damage to the lot..." (Christie's 1994, p. 117). No guarantee applies to the information provided in the lower-case type below the bold type heading (Sotheby's 1989, p. 2). ${ }^{13}$

Rescinding a sale therefore is difficult (Chappell and Polk 2009). Proving that a seller deliberately or carelessly misled a buyer involves a protracted legal process. ${ }^{14}$ The usual auction house practice therefore is to "under-catalogue" (Hook 2013). Senior managers in auction houses are confident in their pre-sale due diligence: "If you sued us you would lose..." ${ }^{15}$ However, in the art world nobody gains from a public and acrimonious legal dispute. US auction houses' conditions of sale (and for online bidders) explicitly deter legal actions by stipulating that any "dispute shall be referred to and finally resolved by arbitration in New York in accordance with the International Arbitration Rules of the International Center for Dispute Resolution". ${ }^{16}$

In practice, auction houses tend to "cancel the sale" and refund disappointed buyers' money to maintain their confidence and loyalty. Most art collectors acquire multiple objects for their collections. A reputation for a gentlemanly attitude toward resolving mistakes is an important aspect of non-price competition in the market. When Sotheby's decision to cancel the sale of a suspected Frans Hals forgery and reimburse USD 11.75 million to the disappointed collector was attacked in a 2019 court case, Sotheby's barrister stated that acting otherwise "would have been corrosive for the art market" (The Art Newspaper 2019).

The top auction houses often choose to absorb losses even though the consignment contract usually contains a rescission clause, meaning that the auction house could undo the sale legally (even after several years) and force the seller to return the money received for the object (Wallace 2010). The top auction houses will do that only in exceptional circumstances-i.e., when they suspect that the seller was involved in deliberate fraud or grossly negligent, such as the case discussed above of Sotheby's suing the Mark Weiss Gallery over the Frans Hals forgery. It would be damaging to an auction house's business if bona fide sellers were concerned that the proceeds from a sale might be demanded back from them until whatever time limit was agreed had elapsed (Wallace 2010). Sotheby's has, in fact, withdrawn several fakes and forgeries from the market, to form a collection sometimes referred to as the "Black Museum" (Kiddell and Bartram 1990). Clearly, reputational private governance solutions are preferable to court action.

The discussion above highlights the efforts undertaken by auction houses to ensure that only authentic pieces enter the high value art market-or that doubts clearly are indicated in advance of the sale. The auction houses bear a significant financial risk if they have to relieve disappointed buyers of essentially worthless objects-although they can purchase insurance to hedge against that risk. All such provisions must be financed. A buyer's premium therefore is charged by adding a percentage to the "hammer price". That premium often is substantial: "On all lots we charge $30.25 \%$ of the hammer price up to and including

\footnotetext{
13 The waiver of liability creates incentives to "improve" objects. For example, entirely bogus swastikas and gothic script sometimes are added to the back of suitable artwork to mark them as (highly collectable) "degenerate art".

14 For example, the Knoedler gallery in New York peddled fakes from 1994 to 2008, but was closed only in November 2011. One of its victims decided to sue and it took 4 years for the case to reach the court (Art News 2016).

15 Interview 21 February 2017.

16 https://onlineonly.christies.com/terms-and-conditions/209, similarly at https://www.sothebys.com/en/ terms-conditions.
} 
$€ 50,000,24.2 \%$ on that part of the hammer price over $€ 50,000$ and up to and including $€ 1,600,000$, and $14.52 \%$ of that part of the hammer price above $€ 1,600,000$ " (Christie's 2016). In addition, the seller generally is charged a commission and may be billed for any expert opinions requested on their behalf.

In summary-carrying out the complex governance functions in the high value art market is expensive. It requires significant internal and external expertise, exhibition and auction rooms in the world's most glamourous (and expensive) locations and (self-) insurance for occasional mistakes. ${ }^{17}$ Collectors and dealers pay the substantial buyers' premium in exchange for the services provided.

\section{Interactions between private and formal governance}

The booming art market has attracted a new class of collectors in recent decades: commercial investors and super-rich businesspeople. Owners of multi-million-dollar objects often are frustrated by the seemingly antiquated art world where scholars openly disparage their "masterpieces" or refuse to authenticate their "finds" based on opaque criteria. Changing social norms on restitution and online research have made it easier for former owners of stolen artworks to locate and reclaim them. Some have turned to the courts to settle authenticity and ownership disputes. How has such litigation affected the functioning of the private governance system?

In the authenticity domain, a series of art fraud cases have raised the bar for due diligence and credible evidence. Auction houses are more cautious in guarding their reputations. They carefully scrutinize the objects, their provenances, and the quality of expert endorsements. Despite the skepticism of art historians and connoisseurs, scientific dating techniques and compositional analysis have become standard procedures whenever concerns are raised. In 2016, Sotheby's acquired its own scientific laboratory for conservation and analysis to reduce the impact of expensive settlements and rising insurance premiums on its bottom line (The Guardian 2018).

Yet, litigation also undermines the functioning of private governance. Many experts are intimidated by the threat of potentially ruinous lawsuits - even if they are likely to be exonerated eventually. The problem arises especially when experts hold negative views on an object's authenticity. For an academic or a trust charged with managing an artist's legacy, it often is better to say nothing than risk a lawsuit funded by high-powered commercial interests. For art produced in artists' workshops judging "authenticity" is particularly problematic. For example, Andy Warhol's famous silkscreen prints largely were produced by studio assistants. Nonetheless, the Warhol Institute's authentication committee regularly considered new submissions for the Andy Warhol Catalogue Raisonné-until disappointed owners of unsuccessful submissions sued. Although the Institute won its cases, its directors dissolved the Warhol authentication board in 2012: the cost of litigation dwarfed the proceeds from authentication services (Fincham 2017; The Observer 2011). Other authentication boards representing artists whose studios mass-produced output followed suit-leading to a "deep freeze in authentication" (Wall Street Journal 2014). Amore (2015, p. 52) cites a

\footnotetext{
17 Second-tier auction houses charge similar buyers' commissions and compete directly with the top auction houses in quality assurance to build reputations for expertise in niche fields, e.g., Bonhams on European ceramics.
} 
letter from Christie's: "It is our belief, and generally accepted in our industry, that Pollock paintings not listed in the catalogue raisonné, are rarely accepted in the market place."

Similarly, when the National Gallery deliberated whether or not to include Salvator Mundi in its 2011 Leonardo exhibition, only two of the five experts consulted wholeheartedly endorsed the painting as Leonardo's work. The two dissenters and the ambivalent scholar kept their opinions private (Lewis 2019). Their caution enabled Christie's to refer to a "broad consensus" of scholarly opinion in favor of a Leonardo attribution in their auction catalog. Academic experts vetting art fairs often prefer to make vague statements about objects "not being in keeping with the high standards of this fair", rather than stating doubts about authenticity. ${ }^{18}$ The threat of litigation thus can suppress an open and honest debate on attributions. Occasionally, the absence of debate allows high-powered interests to sell dubious objects to less informed collectors. However, discerning collectors consult the key experts through their networks discreetly. Thus, Salvator Mundi was turned down by several museums after its exhibition in the British National Gallery before eventually being sold to a Russian, and then to a Middle Eastern magnate (Lewis 2019).

In the title domain, a recent challenge for the art market arose from restitution claims for paintings sold by (usually Jewish) owners under duress or looted in Nazi Germany and occupied Europe. Under nemo dat, no subsequent owner has a full legal title, even if the painting was acquired in good faith after a string of previous sales. Since the mid-1990s, more information has been made available for victims of the Nazi regime to track down stolen paintings. Several paintings were withdrawn during pre-sale viewings: sales proceeded only after restitution claims were settled. Eventually, paintings sold in Europe (especially in Paris) between 1932 and 1945 became unsaleable in the top auction houses (Hook 2013, p. 251). Restitution cases can take several years in the courts and neither side's reputation rises in the process. However, the issue can now be resolved using private dispute resolution services offered by law firms. ${ }^{19}$ The firms compete with businesses such as the Art Recovery Group, which broker deals between current and former owners (Amore 2015; Independent 2016; Private Art Investor 2015).

Public law occasionally conflicts directly with private governance in the art market. Yet, Harris (2018) shows that private governance can still function when agents' legitimacy to govern is challenged by the state. A judge can overrule a respected expert and pronounce an object "more likely than not" to be genuine. However, such judgments do not shift expert consensus on the object's authenticity and the market does not accept them, leaving the object unsaleable (Spencer 2004). Realising that, US judges have become more cautious about getting drawn into disputes on authenticity (New York Times 2012). Similarly, the civil law concept of droit moral gives artists (and sometimes their heirs) the right to authenticate works regardless of their expertise or financial interest in the matter (Fincham 2017). Opportunistic heirs' opinions, while valid legally, do not affect academic opinion on which works properly belong into the historical record. The art world therefore may reject the holders of droit moral as experts and discount or ignore their opinions (Findlay 2004; Spencer 2004, pp. 74, 194).

More problematic is that the droit moral and the US Visual Artists Rights Act 1990 also gives artists the right to disown their works under certain conditions, leaving the affected objects unauthored and unsaleable at public auctions. For disowned works, expert opinions are relegated to facilitating private sales. Yet, artists who use their legal rights to challenge

\footnotetext{
18 Interview with TEFAF vetting expert March 2019.

19 Interview with solicitor June 2018.
} 
owners' property claims (Cady Noland being a famous example) face significant costs: they undermine the demand for their own work among investors and may themselves face litigation (Art SY 2016). Economic self-interest thus ensures that they remain a small minority.

The overall effect of litigation on private governance in the top-tier art market thus is twofold: over time the quality of governance has improved, but the supply of objects that meet the higher standard is restricted. Many artworks effectively are "in limbo" until credible methods are found to settle their statuses. In the meantime, auction houses, dealers and collectors advertise their search for means of unblocking the market, signaling how much they would pay for a credible certificate of authenticity or ownership. As restricted supply creates price inflation, an ever-stronger financial incentive exists for agents to develop the required services.

Our final question is whether the legal system dominates private governance. In true polycentric systems, the rules can be changed by insiders who feel oppressed by them (Ostrom 2010; McGinnis 2016). That likewise is true for the art market. Nemo dat is a territorial rule: other conceptions of justice exist. For example, the Swiss legal system enforces the property rights of bona fide owners. If someone buys an object in good faith, his or her title supersedes that of the original owner after 5 years (Yip 2010). For the original owner, 5 years usually is an unrealistic timeframe: stolen paintings often stay hidden for decades. A New York court pronounced in 1991 that "To place the burden of locating stolen artwork on the true owner and to foreclose the rights of that owner to recover its property if the burden is not met would, we believe, encourage illicit trafficking in stolen art.... ${ }^{20}$ The nemo dat rule therefore perfectly suits the interest of insurers, who must prevent a lively open market in stolen art.

If the major auction houses felt that the Swiss law was more suited for underpinning the trade in high-value art, they could locate in Zurich and Geneva. Yet, they choose to locate in New York: the jurisdiction that upholds the world's toughest form of nemo dat (Yip 2010). Buyers acquiring art with defective titles must be extremely careful about exporting, exhibiting, or selling the objects elsewhere. Locating in New York enhances trust in the system and the reputations of the auction houses. Christie's and Sotheby's sales rooms in London, Hong Kong and Dubai do not engage in regulatory arbitrage. Even for online sales, the terms of sale state explicitly: "This agreement and any rights arising outside this agreement shall be governed by the laws of the state of New York;" 21 moreover, any "action that may arise under the Terms of Use shall be commenced and be heard in the appropriate court in the State of New York, County of New York." ${ }^{22}$ Choosing the toughest law to govern transactions enhances the companies' international reputations.

Generally, the private governance system helps art collectors and investors to avoid entanglement in costly, unpredictable, drawn-out and reputation-damaging litigation. The system has parallels in diamond traders "opting out" of the legal system and creating their own arbitration processes (Bernstein 1992; Richman 2017, Stringham 2003). Law enforcement is used as an "on demand" service. The police are called when market participants identify thieves or fraudsters in their midst but are not deployed against bona fide customers. Dealers thought to be complicit in fraud are dragged through the courts and humiliated publicly-such as the Knoedler and Mark Weiss Galleries. Such punishment strengthens

\footnotetext{
${ }^{20}$ Solomon R. Guggenheim Foundation v. Lubell, 77 N.Y.2d 311, 320 (N.Y. 1991).

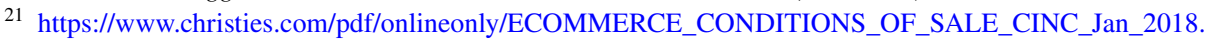
pdf; accessed June 2019.

${ }^{22}$ https://www.sothebys.com/en/terms-conditions; accessed June 2019.
} 
the incentives for others to safeguard their reputations. The fear of scandal and the potential cost of having to defend their opinions, techniques and practices in court leads experts to withdraw from the business when they become aware of weaknesses in their procedures. In the short run, such exit can paralyze specific market segments, but in the longer term it enhances the resilience of the system as improved services emerge.

Changes in societal norms - restitution being an excellent example-are sometimes signaled by court cases. Once the case law is defined clearly, the private governance regime reacts. For individuals, litigation is so cumbersome and expensive that it is better for the market to freeze. Large-scale trading resumes when a viable private governance alternative is developed. Most restitution disputes now are resolved voluntarily for reputational gain and mutual financial advantage by negotiation, or arbitration.

\section{Conclusions}

The market for fine art is challenged continually by criminals and unfortunate, innocent owners of stolen or faked paintings. Art is a credence good: confidence in the system is essential for high prices to be paid and received. Trust can be considered to be a common pool resource that is depleted by opportunism, crime, fraud and negligence. We showed that formal law alone cannot sustain trust: the "art police" is under-funded and court cases are cumbersome, costly and embarrassingly public. Insiders therefore have created rules and processes to protect their valuable common pool resource: by restricting access, monitoring transactions, sanctioning defectors and providing cost-effective dispute resolution (Ostrom 2010).

The key to successful private governance is incentive-compatibility. Private actors create and enforce rules when they have a clear profit motive for doing so. Participating at the lucrative top end of the market in fine art-where prices can reach hundreds of millions of dollars - requires a reputation for selling top-quality items with a "no quibbles" guarantee. Reputational concerns, in turn, need a robust screening procedure by agents specializing in knowledge production. Experts must protect their reputations: pleasing sellers with unwarranted authentication or ownership certificates undermines their perceived trustworthiness and future business opportunities. Insurers created governance instruments to foreclose the market in stolen art and to underpin the market for art insurance. Stolen and looted art registers are private enterprises whose reputation is based on providing timely, comprehensive, and accurate information.

Obtaining expert opinions can cost thousands of dollars. That expense is not worthwhile for most objects, but crucial if something is worth a million dollars if it is genuine and just a few hundred dollars if it is not. The market for high value art therefore is well-governed, while the market for cheaper objects is riddled with fakes and looted items. As Ekelund et al. (2017) point out, the rational art thief or forger will target those segments of the market wherein (private) enforcement is lax. The second-tier art market often locates in civil law jurisdictions, which offer stronger protections to sellers (Schwenzer 2016, p. 80) and bona fide owners (Yip 2010). Some internet platforms and freeports offer trading opportunities entirely removed from public scrutiny. A limit therefore exists to what private governance can achieve in tackling art crime. Given the squeeze on public budgets, the "WildWest" situation in the wider art market likely will persist (The Economist 2013).

Private governance in the art market has an interesting relationship to formal legal systems. Auctions for the highest value art are conducted in venues where legal rules reassure 
buyers that failures in private governance will be punished severely. Yet, having chosen a restrictive legal framework, market participants generally prefer private resolution over court action. The law is used by insiders to punish fraud and theft and put rogue traders out of business. Occasionally, the courts clarify or redefine rules and sub-markets freeze. Stopping trade in troublesome objects enhances the overall reputation of the system and drives up prices (and commissions!). Frozen markets thus trigger a search for improved private governance solutions, creating opportunities for new experts and services. The governance system described herein is not a definitive solution to a static problem. It is an evolving system in which competing agents respond continuously to new challenges.

Open Access This article is distributed under the terms of the Creative Commons Attribution 4.0 International License (http://creativecommons.org/licenses/by/4.0/), which permits unrestricted use, distribution, and reproduction in any medium, provided you give appropriate credit to the original author(s) and the source, provide a link to the Creative Commons license, and indicate if changes were made.

\section{References}

Amore, A. (2015). The art of the con. New York: Palgrave Macmillan.

Agnafors, M. (2013). Quality of government: Toward a more complex definition. American Political Science Review, 107(3), 433-445.

Aligica, P. D., \& Boettke, P. (2009). Challenging institutional analysis and development: The Bloomington School. London: Routledge.

Aligica, P. D., \& Tarko, V. (2012). Polycentricity: from Polanyi to Ostrom, and beyond. Governance, 25(2), 237-262.

Ashenfelter, Or. (1989). How auctions work for wine and art. The Journal of Economic Perspectives, 3(3), 23-36.

Ashenfelter, O., \& Graddy, K. (2011). Economics of the art: Sale rates and price movements in art auctions. American Economic Review: Papers \& Proceedings, 101(3), 212-216.

Bandle, A. L., \& Theurich, S. (2011). Alternative dispute resolution and art-law: A new research project of the Geneva Art-Law Centre. Journal of International Commercial Law and Technology, 6(6), 28-41.

Baumol, W. (1986). Unnatural value: Or art investment as floating crap game. The American Economic Review, 76(2), 10-14.

Bernstein, L. (1992). "Opting out of the legal system: Extralegal contractual relations in the diamond industry. The Journal of Legal Studies, 21(1), 115-157.

Chappell, D., \& Polk, K. (2009). Fakers and forgers, deception and dishonesty: An exploration of the murky world of art fraud. Current Issues in Criminal Justice, 20(3), 393-412.

Charney, N. (2015). The art of forgery. London: Phaidon Press.

Cole, D. H., \& McGinnis, M. D. (Eds.). (2015). Elinor Ostrom and the Bloomington School of Political Economy: Polycentricity in Public Administration and Political Science. Lanham, MD: Lexington Books.

Durney, M. (2011). How an art theft's publicity and documentation can impact the stolen object's recovery rate. Journal of Contemporary Criminal Justice, 27(4), 438-448.

Ekelund, R. B., Jr., Jackson, J. D., \& Tollison, R. D. (2017). The economics of American art: Issues, artists and market institutions. Oxford and New York: Oxford University Press.

Felch, J., \& Frammolino, R. (2011). Chasing Aphrodite: The hunt for looted antiquities at the world's richest museum. Boston: Houghton Mifflin.

Fincham, D. (2017). Authenticating art by valuing art experts. University of Mississippi Law Journal, 86(2), $586-629$.

Findlay, M. (2004). The catalogue raisonne. In R. D. Spencer (Ed.), The expert vs. the object. Oxford and New York: Oxford University Press.

Greif, A. (1993). Contract enforceability and economic institutions in early trade: The Maghribi traders' coalition. American Economic Review, 83(3), 525-548.

Ginsburgh, V., \& Van Ours, J. (2003). Expert opinion and compensation: Evidence from a musical competition. American Economic Review, 93(1), 289-296. 
Harris, C. (2018). Institutional solutions to free-riding in peer-to-peer networks: A case study of online pirate communities. Journal of Institutional Economics, 14(5), 901-924.

Landa, J. (1994). Trust, ethnicity and identity. Ann Arbor, MI: University of Michigan Press.

Lervik, T., \& Balcells, M. (2014). Corruption from the top: The Getty and Caligula's legacy. In Joris Kila \& Mark Balcells (Eds.), Cultural property crime. Leiden: Brill Publishers.

Gill, D., \& Tsirogiannis, C. (2016). Polaroids from the Medici Dossier: Continued sightings on the market. In N. Charney (Ed.), Art crime. London: Palgrave Macmillan.

Hook, P. (2013). Breakfast at Sotheby's: An A-Z of the art world. London: Penguin Books.

Kiddell, A., \& Bartram, J. (1990). Fakes and forgeries; an exhibition incorporating Sotheby's "Black Museum”. London: Sotheby's.

Leeson, P. T. (2008). Social distance and self-enforcing exchange. Journal of Legal Studies, 37(1), 161-188.

Leeson, P. T. (2014). Pirates, prisoners, and preliterates: Anarchic context and the private enforcement of law. European Journal of Law and Economics, 37(3), 365-379.

Lewis, B. (2019). The last Leonardo. London: William Collins.

McGinnis, M. D. (Ed.). (1999). Polycentricity and local public economies: Readings from the workshop in political theory and policy analysis. Ann Arbor: University of Michigan Press.

McGinnis, M. D. (2016). Polycentric governance in theory and practice: dimensions of aspiration and practical limitations. http://depts.washington.edu/envirpol/wp-content/uploads/2016/02/McGinnis_paper .pdf.

Ostrom, E. (1990). Governing the commons: The evolution of institutions for collective action. Cambridge and New York: Cambridge University Press.

Ostrom, E. (2005). Understanding institutional diversity. Princeton, NJ: Princeton University Press.

Ostrom, E. (2010). Beyond markets and states: Polycentric governance of complex economic systems. American Economic Review, 100(3), 641-672.

Ostrom, V. (1972). Polycentricity. Paper presented at Annual Meeting of the American Political Science Association, Washington, D.C., Sept. 5-9, 1972. Reprinted in McGinnis, M.D. (1999).

Ostrom, V., Tiebout, C. M., \& Warren, R. (1961). The organization of government in metropolitan areas: A theoretical inquiry". American Political Science Review, 55(4), 831-842.

Plattner, S. (1998). A most ingenious paradox: The market for contemporary fine art. American Anthropologist, $100(2), 482-493$.

Polanyi, M. (1951). The logic of liberty. Chicago: University of Chicago Press.

Richman, B. (2017). Stateless commerce: The diamond network and the persistence of relational exchange. Cambridge MA: Harvard University Press.

Rogge, C. E., \& Arslanoglu, J. (2019). Luminescence of coprecipitated titanium white pigments: Implications for dating modern art. Science Advances, 5(5), 1-7.

Roodt, C. (2015). Private international law, art and cultural heritage. Cheltenham: Elgar.

Salisbury, L., \& Sujo, A. (2009). Provenance. New York: Penguin Books.

Salter, B. (2001). Who rules? The new politics of medical regulation. Social Science and Medicine, 52(6), $871-883$.

Schwenzer, I. (2016). The CISG: A fair balance of the interests of the seller and the buyer. In I. Schwenzer, C. Pereira, \& L. Tripodi (Eds.), CISG and Latin America, regional and global perspectives. The Hague: Eleven International Publishing.

Shortland, A. (2018). Governing criminal markets: The role of private insurers in kidnap for ransom. Governance, 38(1), 345-361.

Singer, L., \& Lynch, G. (1997). Are multiple art markets rational? Journal of Cultural Economics, 21(3), 197-218.

Singer, L., \& Lynch, G. (1994). Public choice in the tertiary art market. Journal of Cultural Economics, 18(3), 199-216.

Spencer, R. D. (Ed.). (2004). The expert vs. the object. Judging fakes and false attributions in the visual arts. Oxford and New York: Oxford University Press.

Stringham, E. (2003). The extralegal development of securities trading in seventeenth-century Amsterdam. The Quarterly Review of Economics and Finance, 43(2), 321-344.

Tarko, V. (2015). Polycentric structure and informal norms: Competition and coordination within the scientific community innovation. The European Journal of Social Science Research, 28(1), 63-80.

Thorsby, D. (1994). The production and consumption of the arts: A view of cultural economics. Journal of Economic Literature, 32(1), 1-29.

Wallace, J. (2010). Your art sold at Christie's or Sotheby's auction. Can the auctioneer undo your sale years later? Probably, yes; Spencer's Art Law Journal 1(1), online.

Watson, P. (2007). The Medici conspiracy: The illicit journey of looted antiquities- from Italy's tomb raiders to the world's greatest museums. New York: BBS PublicAffairs. 
Yip, A. (2010). Stolen art: who owns it often depends on whose law applies Spencer's Art Law Journal 1(1), online.

\section{Newspaper and Online Sources}

Al Ahram 17 December 2013. Egyptian antiquities ministry tries to stop sale of 23 artefacts in US.

ArtBasel 2018. The Art Market 2018.

ArtBasel 2019. The Art Market 2019.

Artnews 25 April 2016. The big fake: behind the scenes of Knoedler gallery's downfall.

Artbusiness Newspaper. 9 October 2015. The Bizarre World of Art Theft.

Art SY 21 June 2016 How Much Control Do Artists Have over a Work after It's Sold?

BBC News 6 October 2016. Sotheby's declares 'Frans Hals' work a forgery.

Christie’s 26 January 2016. Christie’s art sales in 2015 total $£ 4.8$ billion/ $\$ 7.4$ billion.

Deloitte and ArtTactic. 2016. Art and Finance Report.

FBI Law Enforcement Bulletin. March 2012. Protecting Cultural Heritage from Art Theft: International Challenge, Local Opportunity $\square$.

National Geographic 17 April 2015. Why Shroud of Turin's Secrets Continue to Elude Science.

New York Time 5 October 2012: Ruling on Artistic Authenticity: The Market vs. the Law.

New York Times. 20 September 2013 Tracking Stolen Art, for Profit, and Blurring a Few Lines.

Private Art Collector 18 May 2014. Chubb launches fine art practice.

Private Art Investor 6 March 2015. Art Recovery Group: Tracking Stolen Art.

Reuters. 16 November 2016. Monet Painting Sells for Record \$81.4 Million at Christie’s.

The Art Newspaper. 11 January 2016. Owner of purported Monet loses case in French court.

The Art Newspaper. 4 March 2016. French police seize painting attributed to Cranach, owned by the Prince of Liechtenstein.

The Art Newspaper. 29 August 2016. What we learned from the Knoedler fakes scandal.

The Art Newspaper 11 April 2019 Court case over 'modern forgery' Frans Hals concludes.

The Economist 23 November 2013. Ueber-warehouses for the ultra-rich.

The Financial Times 28 June 2015. How antiquities are funding terrorism.

The Financial Times 5 October 2016. Old Master market reels from Sotheby's fake assessment.

The Guardian 3 July 2015. Looted in Syria - and sold in London.

The Guardian 10 March 2016. World art market stalls for first time in years.

The Guardian 15 June 2018. How to spot a perfect fake.

The Independent 20 March 2014. Picasso's handyman ordered to return $£ 50$ million 'lost' artworks.

The Independent 27 January 2016. Stolen art tracking companies ALR and ARG embroiled in 'bizarre' legal row.

The Observer. 19 October 2011. Warhol Foundation Dissolves Authentication Board.

The Telegraph 16 August 2017. Met Police unit tasked with targeting art thieves faces closure after detectives moved to cover Grenfell tragedy.

Wall Street Journal 24 April 2014. The Deep Freeze in Art Authentication.

\section{Auction Catalogs}

Christie's. Fine Antiquities 7 December 1994.

Christie's. Centuries of Style. 7 June 2011.

Christie's. Modern Art 13 December 2016, Amsterdam.

Sotheby's. Antiquities and Islamic Art 23 June 1989.

Publisher's Note Springer Nature remains neutral with regard to jurisdictional claims in published maps and institutional affiliations. 